\title{
What do EFL Students Think and Feel About Concordancing?
}

\author{
Jonathan Aliponga \\ Kansai University of International Studies, Hyogo, Japan \\ E-mail:alipongaj@kuins.ac.jp
}

Doi:10.5901/ajis/2013.v1n2p11

\section{Abstract:}

Using high-speed computers, it is now possible to use concordancers, which are recognized by educators as a potentially useful tool, as a means to develop vocabulary and understand language structures in real language context. In this study, three concordancers as well as two concordancing related tasks were introduced to high proficient EFL students. Using a 20-item survey questionnaire, students' perceptions of and attitudes toward the use of concordancers and the concordancing related tasks (e.g., vocabulary diary and gap-fill tasks) were determined. In addition, implications of the findings for teaching and learning in EFL contexts were discussed.

Keywords: concordance; concordancer; concordancing; vocabulaty learning; grammar; technology

\section{Introduction}

I have been a firm believer in the power of information technology to make teaching and learning successful. That is why a few years ago, I decided to utilize WebCT to develop course materials for my doctorate dissertation. I designed the interactive on-line materials and used them to find out if these could develop ESL students' proficiency in verb tenses and discourse competence. Results revealed that the interactive on-line materials were effective in developing students' proficiency in verb tenses and discourse competence. Currently I am utilizing concordancer in my EFL classroom.

Concordancing is a technique in which a large body of text (called a corpus) is analyzed by a computer program to discover the regular patterns and lexical sets that are associated with a specific word or phrase (Hadley, 200I). Language corpora can be either collections of written or spoken texts; for example, collections of written texts can be extract from newspapers, business letters, popular fictions, books, or magazines, published or unpublished school essays and etc. (Hasselgård, 200I). If planned carefully, the use of corpora can bring many benefits to students and teachers. One benefit is that it provides high speed searching tool (Chen, 2004). Unlike relying heavily on dictionaries as the main source to look up word definitions and examples which is often too laborious and timeconsuming, by using the concordance tool of corpora to search for word contexts, learners are involved in a more speedy and efficient language learning experience (Cobb, 2003). Another advantage of using corpora is that it accelerates lexical growth while promoting the noticing of 'word grammar' as an integral part of vocabulary study (Cambrensis \& Gillway, 2006). The rationale is based on the premise that students learn to use words best by encountering multiple examples of a word used in novel contexts and being guided to notice how that word is used. Willis and Willis (1996) refer to "notice how that word is used" as consciousness-raising. By providing learners with consciousness-raising activities, they are encouraged to think about samples of language and to draw their own conclusions about how the language works.

Speaking of vocabulary, Freebody and Anderson (198I) emphasize that word knowledge is the 
key ingredient in successful reading in both the LI and L2 (Cooper, I984) contributing more to L2 academic reading success than other kinds of linguistic knowledge including syntax (Saville-Troike, 1984). As Wilkins stated as far back as I972, "Without grammar very little can be conveyed; without vocabulary nothing can be conveyed."

Lexical knowledge is important to a language, but lexical items also have grammar. As Lewis (1993) stated, 'Language consists of grammaticalized lexis, not lexicalized grammar.' KWIC or concordance output helps to reveal not only the collocations (words that co-occur regularly), but also the colligations (grammatical patterns that co-occur regularly) of a lexical item. As Lewis recommended in TESOL Arabia Conference in 2003, we should teach words with the useful grammar included, not take things apart, presenting words out of their grammatical context.

In the present study, I introduced to students the on-line concordance websites which they utilized to unlock the lexical items from the academic listening passages. Although the main skill focus of the course was listening, I integrated into the course the vocabulary that students have learned from their academic reading course. This provided students the opportunity to put into meaningful practice what they have acquired.

Although there have been a number of studies showing the benefits of using concordance in vocabulary learning mentioned in the above studies, there is a limited research on examining students' perceptions of and attitude toward the use of concordancer, especially in EFL contexts like Japan. Marzano (1992) points out one important dimension of learning, that is positive attitudes and perceptions about learning. Furthermore, he emphasizes that without positive attitudes and perceptions, students have little chance of learning proficiently, if at all. The goal of the present study was to determine how college students perceived the use of concordancer in the classroom and how they felt about it after using it. The specific questions this study sought to answer are:

I. What are students' perceptions of the use of concordancer in the classroom?

2. What are students' attitudes toward the use of concordancer in the classroom?

3. What are the implications of the results for teaching and learning?

\section{Research Methodology}

\section{I Participants}

Participants involved in this study were ten second year college students at a private university in Hyogo, Japan. These students, who major in English language education, belonged to the high level group based on their TOEFL ITP scores. Based on the proficiency identified by the American Council for the Teaching of Foreign Languages (1985), the speaking ability of this group is advanced which is characterized by the speaker's ability to converse in a clearly participatory fashion. These students could initiate, sustain, and bring to closure a wide variety of communicative tasks, including those that require an increased ability to convey meaning with diverse language strategies due to a complication or an unforeseen turn of events. They also could satisfy the requirements of school and work situations, and narrate and describe with paragraph-length connected discourse.

\subsection{Instrument}

The instrument utilized in this study is a 20-item survey questionnaire. The questionnaire is divided into two parts. Part I has I0 items about students' perceptions of the use of concordancer. The variables reflected in the statements in the questionnaire were adopted from the results of previous studies on the effects of concordancing: on vocabulary building and determining collocations (Barlow, I996a; Cobb, 
1999; Lin, 2003); on identifying useful phrases and grammatical patterns, and making generalizations about the meaning and grammatical patterns of a word (St. John, 200I; Todd, 200I; Wang, 200I); and on providing students with high speed vocabulary searching tool (Chen, 2004). The other two statements, one is about the usefulness of the worksheet or vocabulary diary for learning the general and academic vocabulary, and the other is about the usefulness of the gap-filling task for learning collocations, were adopted from Chen's (2004) study.

Statements $I$ and 7 are about the perception of concordancer for learning vocabulary in general. Statements 2, 3, 4, 5, 6, 8 pertain to the perception of the use of concordancer for identifying useful phrases; determining collocations; identifying grammatical patterns; making generalizations about the meaning of a word; making generalizations about the grammatical patterns of a word; and providing students with high speed vocabulary searching tool, respectively. While statement 9 pertains to the perception of the use of worksheet or vocabulary diary as being useful for learning the general and academic vocabulary, statement IO relates to the perception of the use of gap-filling task as being useful for learning collocations.

Part 2 also has 10 statements about students' attitudes toward the use of concordancer. The focus of each statement in this part is the same as the one in Part I. For example, statements I and 7 relate to the students' attitude toward the use of concordance for learning vocabulary in general.

The use of the term "like" to measure students' attitude was adopted from the questionnaire utilized by Savignon and Wang (2003) in their study of students' perceptions of and attitudes toward communicative language teaching. Responses were scored on a 5-point scale from Strongly Disagree (I) to Strongly Agree (5).

Accuracy of each statement was checked by an independent group of professors of English language. The questionnaire was piloted with a different group of similar participants to determine if there were any ambiguous or confusing items.

\subsection{Procedure}

This study was part of my Academic Listening I course which I taught for one semester for I5 weeks. The main goal of this course was to develop students' ability to understand spoken English from North America and other English-speaking countries. To function successfully in academic environments, students need to acquire the listening skills, especially listening to lectures and conversations (www.ets.org/toefl ). Specifically, students should have the ability to listen for basic comprehension and pragmatic understanding, and they should be able to connect and synthesize information. In order to achieve these goals, students should have enough vocabulary. As mentioned earlier in this study, lexical items have grammar and lexical knowledge is important to a language (Lewis, 1993). As far as teaching is concerned, Lewis recommended that we should teach words with the useful grammar included, not take things apart, presenting words out of their grammatical context. Concordancer is useful for this purpose because it reveals not only the collocations (words that co-occur regularly), but also the colligations (grammatical patterns that co-occur regularly) of a lexical item.

Taking into account Lewis' recommendation, I utilized the vocabulary from the listening and reading passages in the TOEFL iBT textbook. I introduced to students three concordance websites, and concordancing related tasks such as the vocabulary diary and gap-fill tasks. It took about six class meetings (I class was 90 minutes and held twice a week) to train students how to use the concordance websites, what and how to write in the vocabulary diary, and how to construct the gap-fill tasks.

One concordance website utilized in this study is the one conceptualized by Chris Greaves of Hong Kong Polytechnic and coded in PERL by Tom Cobb of UQAM Montreal, Canada (http://vlc.polyu.edu.hk/). This concordance is one of the language projects presented by the Virtual 
Language Centre in Hong Kong. Users can search for language samples from various corpora such as students' academic writings, Time Magazines, the Bible, business and economy, etc. The other concordance website is the British National Corpus (BNC) (http://www.natcorp.ox.ac.uk/). It is one of the most famous corpora consisting of 100 million collections of written and spoken language samples. Finally is the Corpus of Contemporary American English (http://corpus.byu.edu/coca/) which contains 425 million words from various sources such as magazines, newspapers, fiction, television shows, etc.

The concordance diary (see Appendix B), which is referred to as concordance sheet by Chen (2004), is where students kept at least two examples of the vocabulary contexts from the concordance websites. Students chose several examples that were meaningful and comprehensible to them and kept those examples in their vocabulary diary.

Regarding the gap-fill task (see Appendix C), which was also conceptualized by Chen (2004), students used the authentic contexts searched from corpora to compose a gap-fill sheet for them to work on. For example, the target word from the listening or reading passage was 'pass'. Students in pairs searched using the concordancer several collocations such as pass on, pass to, pass by, pass away, pass along, etc. Based on the contexts, they discussed the meaning of the collocations. Student volunteers wrote the collocations on the board. Then I asked them to clarify the collocations they did not understand. To maximize student participation, I asked those who understood the meaning to give situations using that collocation which other students found difficult. As a homework, students had to individually construct a multiple choice gap-fill task for each collocation (see Appendix C) using the concordance websites. In the next class, they exchanged with each other and answered the gap-fill task. To make sure students understood all the collocations in the homework, I had to conduct whole class processing for those collocations students missed to answer correctly.

Students used their laptop computer to write their vocabulary diary and construct the gap-fill tasks. They saved them in the on-line share folder on the university website.

\section{Results}

Table I. Perceptions of and Attitudes Toward Concordancing Tool for Vocabulary Learning

\begin{tabular}{|llllll|}
\hline & $\mathrm{n}$ & mean & SD & $\mathrm{t}$ & $\mathrm{p}$ \\
\hline Perception & $\mathrm{I}$ & 3.50 & & & \\
& & & .22 & $\mathrm{I} .23$ & 0.25 \\
Attitude & 10 & 3.42 & & & \\
\hline
\end{tabular}

$\mathrm{p}<0.05$

The mean (3.50) for perceptions shows that students had positive perceptions of the use of concordancer in the listening course. This means that students thought that concordancer was useful for vocabulary learning, identifying useful phrases, identifying collocations, identifying grammatical patterns, and for challenging them to actively make generalizations about the meaning of a word and the grammatical patterns of a word. Students also perceived that concordancer provided them with high speed vocabulary searching tool. As far as vocabulary diary and gap-fill tasks were concerned, students thought they were useful for learning the general andacademic vocabulary, and for learning collocations, respectively.

As for students' attitudes, the mean (3.42) reveals that students also had positive attitudes toward the use of concordancer in the listening course. Specifically, students had positive attitudes toward the use of concordancer for vocabulary learning, identifying useful phrases, identifying collocations, 
identifying grammatical patterns, and for challenging them to actively make generalizations about the meaning of a word and the grammatical patterns of a word. Students also had positive attitudes toward the use of concordancer in providing them with high speed vocabulary searching tool. As far as vocabulary diary and gap-fill tasks were concerned, students had positive attitudes toward their usefulness for learning the general and academic vocabulary, and for learning collocations, respectively.

The t-test $(t=1.23)$ shows that there is no significant difference between perceptions and attitudes. This means that students who had positive perceptions of the use of concordancer also had positive attitudes toward the use of concordancer. Pearson correlation $(p=+0.25)$ reveals no significant correlation between perceptions and attitudes because of the small sample size $(n=10)$.

\section{Discussion and Conclusion}

The results of the study show that high level EFL college students had positive perceptions of and attitudes toward the use of concordancer and concordancing related tasks (e.g., vocabulary diary and gap-fill tasks) in the classroom particularly in vocabulary learning, identifying useful phrases, identifying collocations, identifying grammatical patterns, and for challenging them to actively make generalizations about the meaning of a word and the grammatical patterns of a word.The findings of this study support the results of the study of Chujo, Miura and Uchiyama (2006) whose goal was to use the corpus and CALL listening material and vocabulary learning material to improve students' communicative proficiency. The findings of this study also find support in the study of Cambrensis and Gillway (2006) which found concordancer to accelerate lexical growth while promoting the noticing of 'word grammar' as an integral part of vocabulary study. Concordancer was also efficient in that it presented multiple examples of a word at one time, and effective in drawing multiple examples of a word together in one place that highlighted certain patterns.

Students in this study also had positive perceptions of and attitudes toward concordancer's capability to provide them with high speed vocabulary searching tool. By using the concordance tool of corpora to search for word contexts, learners were involved in a more speedy and efficient language learning experience (Cobb, 2003).

As far as vocabulary diary and gap-fill tasks were concerned, students thought that the vocabulary diary was useful for learning the general and academic vocabulary, and gap-fill tasks were useful for learning collocations. Students also had positive attitudes toward the use of vocabulary diary and gap-fill tasks for the above purposes. By utilizing vocabulary diary and gap-fill tasks, this study has demonstrated how to create more traditional vocabulary activities (e.g., fill-in-the-blank or matching exercises) that have the added advantage of being based on authentic texts and also exposing learners to multiple, novel contexts at one time (Stevens, I99I; Thurstun \& Candlin, 1998). For example, Stevens (I99I) found that concordance-based vocabulary exercises can be more easily solved by learners than traditional gap-filler exercises like the gap-fill tasks in this study, suggesting they should be used "if the purpose of the exercise is to reinforce the vocabulary, as opposed to testing, and if the proclivity of the teacher is to engender a sense of confidence and well-being in the students" (p. 55).

Although students had positive perceptions of and attitudes toward the use of concordance, vocabulary diary and gap-fill tasks, the ratings were not highly positive. It took about six 90 minutes to train students to use the concordance websites as well as the vocabulary diary and gap-fill tasks. This low rating might be due to the fact that students found using the concordance websites difficult. While checking students doing the concordance activities, I received feedback from many saying that finding easy-to-comprehend contexts where the vocabulary was used was difficult and time consuming. The results of this study corroborate the findings of studies on DDL activities which low proficient students found them complicated or difficult to complete (Hadley, 2002). The findings are also consistent with 
the results of the studies of Tono(2003) and Umesaki (2004) which found English concordance examples retrieved to be difficult for beginning level learners to understand .

To conclude, the results of the study reveal that, despite the difficulty of using concordancer in finding comprehensible word contexts, the students had positive perceptions and attitudes toward the use of concordancer, vocabulary diary and gap-fill tasks for vocabulary building, determining collocations, identifying useful phrases and grammatical patterns, making generalizations about the meaning and grammatical patterns of a word, and providing students with high speed vocabulary searching tool. An understanding of learner attitudes and their perceptions of the pedagogical benefits of concordancer and the tasks related to it will enable teachers to best utilize concordancer in the classroom in order to achieve those pedagogical benefits.

\section{Limitations}

The ten respondents utilized in this study were all students registered in the academic listening course. Due to the small sample size, the positive perceptions and attitudes expressed for the use of concordancer and the concordancing related tasks (e.g., vocabulary diary and gap-fill tasks) in order to achieve benefits (e.g. identifying collocations) cannot represent the views of students in the department in the university where the study was conducted. In addition, the respondents were high proficient and they cannot represent the views of low and average proficient students.

\section{Implications}

Despite the difficulty students encountered, the findings suggest that the use of concordancer and the performance of the tasks such as the vocabulary diary and gap-fill tasks are useful for vocabulary building, determining collocations, identifying useful phrases and grammatical patterns, making generalizations about the meaning and grammatical patterns of a word, and providing students with high speed vocabulary searching tool. Learners have to fully comprehend that the advantages outweigh the disadvantages. The results also tell us that there is a need to provide students with enough practice how to use the concordance websites and do the concordance related tasks until they become familiar with and successful using them. As far as language proficiency is concerned, the findings suggest that the contexts or corpora in the concordancers might be too difficult for low proficient or beginning level students which may demotivate them to accomplish the concordancing related tasks.

\section{References}

American Council for the Teaching of Foreign Languages (1985). ACTFL proficiencyguidelines. Retrieved from proficiencyguidelines/contents.htm . http://www.sil.org/lingualinks/languagelearning/otherresources/actfl

Barlow, M. (1996b). Corpora for theory and practice. International Journal of CorpusLinguistics, I(I), I-37.

Cambrensis, J. and Gillway, M. (2006). The study of selected vocabulary in context -using technology to motivate learners. UGRU Journal, 3. Retrieved from http://www.ugruenglish.uaeu.ac.ae/ ugrujournal/ugrujournal_files/sr3/vocabcontext.pdf

Chen, Y.H. (2004). The use of corpora in the vocabulary classroom. The Internet TESL Journal, X, (9). Retrieved from http://iteslj.org/Techniques/Chen-Corpora.html

Chujo, K., Miura, S., and Uchiyama, M. (2006). Using A Japanese-English parallel corpus for teaching English vocabulary to beginning-level students. EnglishCorpus Studies, (13), 53-172.

Cobb, T. (1999). Breadth and depth of lexical acquisition with hands-on concordancing. CALL Journal, I2(4), pp. 345-360. 
Cobb, T. (2003). Do corpus-based electronic dictionaries replace concordancers? In Morrison, B., Green, G.\&Motteram, G. (Eds.),Directions in CALL: Experience, Experiments, Evaluation. Polytechnic University:Hong Kong.

Cooper, M. (1984). Linguistic competence of practised and unpractised non-nativespeakers of English. In J.A. Alderson \& A.H. Urquhart (Eds.), Reading in aforeign language (pp. I22-138). London: Longman.

Freebody, P. \& Anderson, R.C. (I98I). Effects of vocabulary difficulty, text cohesion, and schema availability on reading comprehension. Technical Report No. 225. Urbana, IL: University of Illinois Center for the Study of Reading.

Hadley, G..(200I). Concordancing in Japanese TEFL: Unlocking the power of data-driven learning. Retrieved from http://www.nuis.ac.jp/\%7Ehadley/publication/jlearner/jlearner.htm>

Hasselgård, H. (200I). Corpora and their use in research and teaching. Retrievedfrom http://folk.uio.no/hhasselg/UV-corpus.htm

Lewis, M. (1993). The lexical approach. The state of ELT and the way forward. LTP Teacher Training.

Lin, C. C. (2003). Learning collocations in a bilingual corpus. The Proceedings of 2003International Conference and Workshop on TEFL \& Applied Linguistics (pp. 250-256). Taipei: Crane.

Marzano R. J., (1992).A different kind of classroom : Teaching with Dimensions of Learning Alexandria Va.: Association for Supervision and CurriculumDevelopment.

Saville-Troike, M. (1984). What really matters in second language learning for academic achievement? TESOL Quarterly 18, 199-219.

Savignon, S and Wang, C. (2003). Communicative language teaching in EFL contexts:Learner attitudes and perceptions. International Review of Applied Linguistics in Language Teaching, 4I(3), 223-249.

Stevens, V. (I99I). Classroom concordancing: Vocabulary materials derived from relevant, authentic text. English for Specific Purposes, 10, 35-46.

St. John, E. (200I). A case for using a parallel corpus and concordancer for beginners of a foreign language. Language Learning \& Technology, 5, I85-203.

Thurstun, J., \&Candlin, C. N. (1998). Concordancing and the teaching of the vocabularyof academic English. English for Specific Purposes, I7(3), 267-280.

Todd, R. W. (200I). Induction from self-selected concordances and self-correction.System, 29(I), 9I-I02.

Tono, Y. (2003) "Corpus woEigoKyoikunilkasu [What corpora can do for language teaching]." English Corpus Studies, I0: 249-264.

Umesaki, A. (2004) "EigoGakushuu no TamenoDaikibo Corpus no Riyou [Using a large-scale corpus in the classroom]." Paper Presented at the 24th Japan Association for English Corpus Studies (JAECS) Conference, Tokyo, Japan.

Wang, L. (200I). Exploring parallel concordancing in English and Chinese. Language learning \&technology, 5, I74-184.

Wilkins, D. A. (1972). Linguistics in Language Teaching. Edward Arnold.

Willis, J. and Willis, D. I996. Consciousness-raising activities. In Willis, J. andWillis, D. (Eds.), (pp. 63-76).

\section{Appendix A}

\section{Questionnaire for students}

\section{Perceptions of concordancing tool for vocabulary learning}

I. The information provided in concordance lists was useful for vocabulary learning. Strongly Strongly $\begin{array}{lllllll}\text { disagree } & \text { I } & 2 & 3 & 4 & 5 & \text { agree }\end{array}$

2. Concordance lists helped me to identify useful phrases. Strongly

$\begin{array}{lllllll}\text { disagree } & I & 2 & 3 & 4 & 5 & \text { agree }\end{array}$


3. Concordance lists helped me to identify collocations.

$\begin{array}{lllllll}\begin{array}{l}\text { Strongly } \\ \text { disagree }\end{array} & \text { I } & 2 & 3 & 4 & 5 & \begin{array}{l}\text { Strongly } \\ \text { agree }\end{array}\end{array}$

4. Concordance lists helped me to identify grammatical patterns.

Strongly

$\begin{array}{lllllll}\text { disagree } & \mathrm{I} & 2 & 3 & 4 & 5 & \text { agree }\end{array}$

5. The use of concordance lists challenged me to actively make generalizations about the meaning of a word.

$\begin{array}{lllllll}\begin{array}{l}\text { Strongly } \\ \text { disagree }\end{array} & \text { I } & 2 & 3 & 4 & 5 & \begin{array}{l}\text { Strongly } \\ \text { agree }\end{array}\end{array}$

6. The use of concordance lists challenged me to actively make generalizations about the grammatical patterns of a word.

Strongly $\begin{array}{lllllll}\text { disagree I } & 2 & 3 & 4 & 5 & \text { agree }\end{array}$

7. Concordance was useful for building vocabulary knowledge.

Strongly

$\begin{array}{lllllll}\text { disagree } & \text { I } & 2 & 3 & 4 & 5 & \text { agree }\end{array}$

8. Concordance provided me with high speed vocabulary searching tool.

$\begin{array}{lllllll}\begin{array}{l}\text { Strongly } \\ \text { disagree }\end{array} & \text { I } & 2 & 3 & 4 & 5 & \text { Strongly } \\ \text { agree }\end{array}$

9. The worksheet or vocabulary diary was useful for learning the general and academic vocabulary.
Strongly
$\begin{array}{llllll}\text { disagree } & \mathrm{I} & 2 & 3 & 4 & 5\end{array}$
Strongly

I0. The gap-filling task was useful for learning collocations. Strongly

$\begin{array}{lllllll}\text { disagree } & \mathrm{I} & 2 & 3 & 4 & 5 & \text { agree }\end{array}$

\section{My attitude toward the concordancing tool for vocabulary learning}

I. I liked the information provided in concordance lists because it was useful for vocabulary instruction.

$\begin{array}{lllllll}\begin{array}{l}\text { Strongly } \\ \text { disagree }\end{array} & \text { I } & 2 & 3 & 4 & 5 & \begin{array}{l}\text { Strongly } \\ \text { agree }\end{array}\end{array}$

2. I liked the concordance lists because they helped me to identify useful phrases.
Strongly

$\begin{array}{lllllll}\text { disagree } & \text { I } & 2 & 3 & 4 & 5 & \text { agree }\end{array}$

3. I liked the concordance lists because they helped me to identify collocations. Strongly

$\begin{array}{lllllll}\text { disagree } & \text { I } & 2 & 3 & 4 & 5 & \text { agree }\end{array}$

4. I liked the concordance lists because they helped me to identify grammatical patterns.

$\begin{array}{lllllll}\begin{array}{l}\text { Strongly } \\ \text { disagree }\end{array} & \text { I } & 2 & 3 & 4 & 5 & \begin{array}{l}\text { Strongly } \\ \text { agree }\end{array}\end{array}$

5. I liked the use of concordance lists because they challenged me to actively make generalizations about the meaning of a word.

$\begin{array}{lllllll}\begin{array}{l}\text { Strongly } \\ \text { disagree }\end{array} & \text { I } & 2 & 3 & 4 & 5 & \begin{array}{l}\text { Strongly } \\ \text { agree }\end{array}\end{array}$

6. I liked the use of concordance lists because they challenged me to actively make generalizations about the grammatical patterns of a word.
Strongly
disagree
2
34
5
Strongly
agree 
7. I liked concordancer because it was useful for building my vocabulary knowledge.

$\begin{array}{lllllll}\begin{array}{l}\text { Strongly } \\ \text { disagree }\end{array} & \text { I } & 2 & 3 & 4 & 5 & \begin{array}{l}\text { Strongly } \\ \text { agree }\end{array}\end{array}$

8. I liked concordancer because it provided me with high speed vocabulary searching tool.

$\begin{array}{lllllll}\begin{array}{l}\text { Strongly } \\ \text { disagree }\end{array} & \text { I } & 2 & 3 & 4 & 5 & \begin{array}{l}\text { Strongly } \\ \text { agree }\end{array}\end{array}$

9. I liked the use of the worksheet or vocabulary diary because it was useful for learning the general and academic vocabulary.
Strongly
$\begin{array}{lllllll}\text { disagree } & \mathrm{I} & 2 & 3 & 4 & 5 & \text { agree }\end{array}$

IO. I liked the use of the gap-filling tasks because it was useful for learning collocations.

$\begin{array}{lllllll}\begin{array}{l}\text { Strongly } \\ \text { disagree }\end{array} & \text { I } & 2 & 3 & 4 & 5 & \begin{array}{l}\text { Strongly } \\ \text { agree }\end{array}\end{array}$

\section{Appendix B}

\section{Sample vocabulary diary}

(So)

The President's second sentence of his State of the Union speech last year said we all know that the primary question is jobs and the economy. So they spent a year on health care.

(Can look like)

If Clark suffocated, why is the blanket that was wrapped around the victim's head so bloody? The B composition fluid canlooklike blood.

(Sort of)

It's the First Lady Michelle Obama's birthday but her husband is not gonna consider the new ABC News /Washington Post poll any sortof gift.

(Look like)

I have seen a picture of the baby. I have no idea. It doesn't looklike my children.

(Found)

We bought a house in Orlando, Florida, in January 2007, and currently owe more than what it's worth. My husband was laid off from his job, and after nine months he found new employment in New Jersey.

(Kind of)

They are influencing the process. They hire lobbyists. They hire public affairs firm. They contribute to candidates. They do all that kindof stuff.

(Shiny)

I actually disagree with Senator Baker. I agree that he is no JFK in terms of charisma and his suit is a little too shinnies and he has scared people in his little photo opportunity with the Children a few days ago.

(Different shape from)

I had no idea you could partly pull out an animal's insides like this. "A sheep's womb is a differentshapefrom a human womb, "says the surgeon."

\section{Appendix C}

\section{Sample gap-fill task}

Fill in the blank with the correct word. Below are the choices

Take Have See Give Measure Think Enjoy 
I. My boyfriend and I both have roommates, so when my parents went out of town for a long weekend, we decided to advantageof the empty house.

2. It is both humbling and horrifying to know that a 5-year-old with three weeks' worth of lessons under her belt is more capable than I am. But I one

advantage: Unlike children, who are usually forced into activities, I genuinely want to play this thing. I am looking for the joy -- yes, joy -- that comes from making music.

3. __ of the advantageyou've got. You'll be learning all sorts of stuff for the rest of us.

4. The other five men in the room all stared at him. These were his best friends. All men of means, aside from Ryan Crawford, whose father had cut him off years before. And all were men of appetites. They every advantage their names and wealth afforded them. Especially ones that involved women. 